\title{
Ticks on birds in a savanna (Cerrado) reserve on the outskirts of Uberlândia, Minas Gerais, Brazil
}

\author{
Carrapatos em aves de uma reserva do Cerrado na periferia de Uberlândia, Minas Gerais, Brasil \\ Jamile de Oliveira Pascoal ${ }^{1}$; Marcus do Prado Amorim'; Maria Marlene Martins'; Celine Melo'; \\ Eurípedes Luciano da Silva Júnior ${ }^{3}$; Maria Ogrzewalska²; Marcelo Bahia Labruna²; Matias Pablo Juan Szabó1*
}

${ }^{1}$ Laboratório de Ixodologia, Faculdade de Medicina Veterinária, Universidade Federal de Uberlândia - UFU, Uberlândia, MG, Brasil

${ }^{2}$ Departamento de Medicina Veterinária Preventiva e Saúde Animal, Faculdade de Medicina Veterinária e Zootecnia,

Universidade de São Paulo - USP, São Paulo, SP, Brasil

${ }^{3}$ Associação para Gestão Socioambiental do Triângulo Mineiro, Uberlândia, MG, Brasil

Received April 11, 2012

Accepted July 12, 2012

\begin{abstract}
We report tick infestations on birds, in the environment and on domestic animals in a non-forested phytophysiognomy, the savanna-like Cerrado sensu stricto, in a natural reserve on the outskirts of the urban area of Uberlândia, Minas Gerais, Brazil. Overall, 238 birds within 50 species, 15 families and six orders were caught. Passeriformes were the most numerous, with 216 birds $(90.75 \%)$, among which 22 had ticks $(\mathrm{n}=31)$. Within this order, the prevalence of tick infestation was $10.2 \%$, and the abundance and mean intensity were 0.14 and 1.41 , respectively. Only immature ticks of the species Amblyomma nodosum were found on the birds. The tick species found both on animals (Rhipicephalus sanguineus, Rhipicephalus (Boophilus) microplus, Amblyomma cajennense and Dermacentor nitens) and in the environment (Amblyomma dubitatum, Rhipicephalus (B.) microplus and Amblyomma cajennense) were as expected. This difference in tick species between the environment and birds possibly occurred because the sampling of the environment was limited to the ground. This study also highlights the importance of the diverse microenvironments used by ticks and hosts in the same area and the complex ecology of bird-tick relationships. Ecological and epidemiological aspects of the findings are discussed.
\end{abstract}

Keywords: Bird, cerrado, tick, passeriformes, ecology.

\section{Resumo}

Nesse trabalho relatam-se infestaçôes de carrapatos em aves, meio ambiente e em animais domésticos em uma fitofisionomia não florestal, o Cerrado stricto sensu, de uma reserva natural na periferia da área urbana de Uberlândia, Minas Gerais, Brasil. Para tal, 238 aves de 50 espécies foram capturadas, pertencentes a 15 famílias e seis ordens. Passeriforme foi a mais numerosa, com 216 indivíduos (90,75\%), dos quais 22 estavam parasitados com 31 carrapatos. Nos Passeriformes a prevalência de infestaçáo de carrapatos foi de $10,2 \%$, a abundância e intensidade média foi de 0,14 e 1,41, respectivamente. Apenas carrapatos imaturos da espécie Amblyomma nodosum foram encontrados em aves. As espécies de carrapatos encontradas tanto em animais (Rhipicephalus sanguineus, Rhipicephalus (Boophilus) microplus, Amblyomma cajennense, Dermacentor nitens) como no ambiente (Amblyomma dubitatum, Rhipicephalus (B.) microplus, Amblyomma cajennense) foram aquelas já esperadas. Esta diferença de espécies de carrapatos entre ambiente e de aves possivelmente ocorreu porque a amostragem do ambiente se restringiu ao solo. Esse estudo também destaca a importância dos diversos microambientes usados por carrapatos e hospedeiros em uma mesma área e a complexa ecologia das relaçóes ave-carrapato. Aspectos ecológicos e epidemiológicos dos achados são discutidos.

Palavras-chave: Aves, cerrado, carrapato, passeriformes, ecologia. 


\section{Introduction}

Ticks are the most important vectors transmitting pathogens to animals and are only second to mosquitoes in the case of human beings (JONGEJAN; UILENBERG, 2004). Out of the approximately 61 species that occur in Brazil (DANTAS-TORRES et al., 2009), comprehensive information exists in relation to less than a dozen species. Generally these species are those affecting domestic animals, and there is a lack of basic information such as hosts, life cycle and pathogen transmission in relation to most others.

Emergence and re-emergence of tick-borne diseases is currently being witnessed worldwide (OSTFELD; KEESING, 2000; PADDOCK, 2009). Although the exact causes for this are complex, both environmental and human behavioral changes might have a role in it. Territorial mixing of wildlife, domestic animals and humans, in association with habitat fragmentation, increases microorganism circulation from and to natural areas (OSTFELD; KEESING, 2000; QUEIROGAS et al., 2012). Some of these microorganisms are pathogenic to humans and thus, knowledge of vector ecology and life cycles is essential for understanding the epidemiology of emerging diseases.

Recent reports have begun to reveal bird-tick relationships in various biomes and phytophysiognomies in Brazil in a more systematic fashion. Thus, there have been recent records of tick species on birds from the Araucaria forest (ARZUA et al., 2003; ARZUA; BARROS-BATTESTI, 1999); Atlantic forest (LABRUNA et al., 2007; OGRZEWALSKA et al., 2008, 2009a), Amazon (OGRZEWALSKA et al., 2010), Cerrado (ROJAS et al., 1999; TOLESANO-PASCOLI et al., 2010) and northeastern Brazil (OGRZEWALSKA et al., 2011). These studies have shown a role for birds to feed immature ticks, and that these ticks may harbor microorganisms that are potentially pathogenic to humans, such as Rickettsia (OGRZEWALSKA et al., 2009b). These data also suggest that birds might spread ticks and tick-borne diseases between small fragments of natural environment.

The Brazilian "Cerrado" (or savanna) is considered to be a "hotspot" of global biodiversity. However, it is severely endangered by human activities and has suffered severe fragmentation (MYERS et al., 2000), mainly due to agricultural activities (SILVA et al., 2006). This biome is vast (only smaller than the Amazon) and comprises several phytophysiognomies ranging from open fields to forest vegetation. There are only a few reports of bird ticks in this area (MARINI; COUTO, 1997; ROJAS et al., 1999; KANEGAE, 2003; TOLESANO-PASCOLI, 2010; LUZ et al., 2012). Nonetheless, this biome is known to be very rich in birds, totaling as many as 837 species, of which 36 are considered endemic (SILVA, 1995).

We recently began a systematic study of bird-tick relationships in the Cerrado by evaluating hosts from a forest fragment (TOLESANO-PASCOLI et al., 2010). Here, we report on tick infestations on birds, in the environment and on home-dwelling domestic animals in a non-forested phytophysiognomy, the cerrado sensu stricto, in a natural reserve on the outskirts of the urban area of the city of Uberlândia, Minas Gerais, Brazil.

\section{Materials and Methods}

\section{Study site}

Sampling was performed in a savanna (Cerrado) reserve named Reserva Vegetal do Clube de Caça e Pesca Itororó, which is on the outskirts of the city of Uberlândia, state of Minas Gerais, Brazil. The reserve, which is adjacent to the urban area, comprises 127 ha and is approximately eight $\mathrm{km}$ from downtown. Several Cerrado phytophysiognomies are found in the reserve including "cerrado sensu stricto" (vegetation dominated by trees and shrubs that are often 3-8 m tall, giving more than 30\% crown cover but still with a fair amount of herbaceous vegetation between them) and palm swamp ("vereda"), i.e. valley-side marshes where the water table reaches or almost reaches the surface during the rainy season.

\section{Bird sampling}

Birds were caught with the aid of 10 mist nets, each 12 meters long and 3 meters high, during four consecutive seasons: May 2008 (autumn); June 2008 (winter); September and December 2008 (spring); and February 2009 (summer). In each season, bird-catching was undertaken for four hours around dawn, on two consecutive days. Mist nets were set up in "Cerrado sensu stricto" areas. The birds that were caught were identified, weighed and measured, and received metallic bands provided by the National Research Center for Wild Bird Conservation and the Chico Mendes Institute for Biodiversity Conservation (CEMAVE/ICMBIO: Centro Nacional de Pesquisa para Conservação de Aves Silvestres/Instituto Chico Mendes de Conservação da Biodiversidade). Bird-catching was authorized by CEMAVE (license No. 2943). The birds were identified in accordance with Ridgely and Tudor $(1989,1994)$ and Sick (2004), and the nomenclature followed the prescriptions of the Brazilian Committee for Ornithological Records (Comitê Brasileiro de Registros Ornitológicos) (CBRO, 2011).

\section{Tick collection from birds}

The search for ticks was done by blowing the feathers from birds to expose the skin. Ticks were collected with tweezers and placed in plastic containers with leaves to prevent desiccation. After this, the birds were released at the capture site.

\section{Tick collection from vegetation}

Ticks were collected every season for two years (from winter 2007 to autumn 2009) at four sites on the reserve; two coincident with bird capture locations ( $18^{\circ} 59^{\prime} 09.8^{\prime \prime} \mathrm{S}$ and $048^{\circ} 18^{\prime} 03.7^{\prime \prime} \mathrm{W}$, Alt. $828 \mathrm{~m} ; 19^{\circ} 00^{\prime} 13.4^{\prime \prime} \mathrm{S}$ and $048^{\circ} 18^{\prime} 43.5^{\prime \prime}$ W, Alt. $842 \mathrm{~m}$ ) and two in areas with vereda phytophysiognomy (18 $59^{\circ} 15.6^{\prime \prime} \mathrm{S}$ and $048^{\circ} 18^{\prime} 03.1^{\prime \prime} \mathrm{W}$, Alt. $798 \mathrm{~m} ; 1^{\circ} 00^{\prime} 10.3^{\prime \prime} \mathrm{S}$ and $048^{\circ} 18^{\prime}$ 47.1" W, Alt. $825 \mathrm{~m}$ ). Ticks were caught using $\mathrm{CO}_{2}$ traps and cloth dragging. $\mathrm{CO}_{2}$ was used as described elsewhere (SZABÓ et al., 2007) and a white flannel one meter wide and two meters long was dragged over the vegetation, with observations made every 
$20 \mathrm{~m}$. Twenty $\mathrm{CO}_{2}$ traps, five per site, and 160 minutes of dragging, 40 minutes per site, were used in each campaign.

\section{Ticks from domestic animals}

To detect domestic animal infestation with ticks from the reserve, dogs, cattle and horses on four neighboring farm properties were inspected every season from autumn 2008 to summer 2009.

\section{Tick identification}

Birds in Brazil are overwhelmingly parasitized by immature specimens of Amblyomma. Unfortunately, there is no reliable key for identifying Neotropical Amblyomma larvae, and until 2010, there was also no key for Amblyomma nymphs. Thus, identification was done initially by rearing ticks until the adult stage in the laboratory or by molecular methods as described previously (OGRZEWALSKA et al., 2009a, b). Adult ticks and, later on, nymphs were identified under a stereomicroscope, in accordance with morphological criteria and dichotomous keys (ONOFRIO et al., 2006; MARTINS et al., 2010). Voucher tick specimens collected during this study have been deposited in the FAMEV/UFU Tick Collection, Federal University of Uberlândia (accession numbers: 264-267, 325).

The laboratory procedures for tick identification (feeding of ticks on laboratory animals until the adult stage) were approved by the Ethics Committee for Animal Research of the Federal University of Uberlândia (protocol number 007/2008).

\section{Hemolymph test}

Rickettsia is an intracellular bacterium with several species that are pathogenic to humans and transmitted by ticks. Searches for Rickettsia in ticks were performed in the hemolymph of adult ticks. For this purpose, each tick specimen was individually tested using the hemolymph test, as described by Burgdorfer (1970). Briefly, a drop of hemolymph collected from the broken leg of each tick was spread onto a slide and then subjected to Gimenez staining. The slide was then scrutinized under an optical microscope for Rickettsia-like organisms, especially inside hemolymph cells.

\section{Data analysis}

The prevalence, abundance and mean intensity of bird tick infestations were determined (BUSH et al., 1997). Minimum and maximum numbers of ticks per host (variation) were also noted.

\section{Results}

\section{Ticks on birds}

Details of the tick infestations are presented in Tables 1-3. Overall, 238 birds in 50 species, 15 families and six orders were caught (Table 1). Passeriformes were the most numerous with 216 specimens (90.75\%), followed by Apodiformes with nine (3.78\%), Piciformes with seven (2.94\%), Columbiformes with three (1.26\%), Cuculiformes with two $(0.84 \%)$ and Coraciiformes with one bird $(0.42 \%)$.

Table 1.Tick infestation prevalence, abundance, mean intensity and variation of bird orders and families, period 2008-2009, in Uberlândia, MG, Brazil.

\begin{tabular}{|c|c|c|c|c|c|c|c|}
\hline Taxons (Order/family) & Infested/Examined & Prevalence (\%) & Larvae & Nymphs & Abundance & $\begin{array}{c}\text { Mean } \\
\text { intensity }\end{array}$ & Variation \\
\hline Columbiformes & $0 / 3$ & $\mathbf{0}$ & $\mathbf{0}$ & $\mathbf{0}$ & 0 & 0 & 0 \\
\hline Columbidae & $0 / 3$ & 0 & 0 & 0 & 0 & 0 & 0 \\
\hline Cuculiformes & $0 / 2$ & $\mathbf{0}$ & $\mathbf{0}$ & $\mathbf{0}$ & $\mathbf{0}$ & $\mathbf{0}$ & $\mathbf{0}$ \\
\hline Cuculidae & $0 / 2$ & 0 & 0 & 0 & 0 & 0 & 0 \\
\hline Apodiformes & $0 / 9$ & $\mathbf{0}$ & $\mathbf{0}$ & $\mathbf{0}$ & $\mathbf{0}$ & $\mathbf{0}$ & $\mathbf{0}$ \\
\hline Trochilidae & $0 / 9$ & 0 & 0 & 0 & 0 & 0 & 0 \\
\hline Galbuliformes & $0 / 1$ & $\mathbf{0}$ & $\mathbf{0}$ & $\mathbf{0}$ & $\mathbf{0}$ & $\mathbf{0}$ & $\mathbf{0}$ \\
\hline Bucconidae & $0 / 1$ & 0 & 0 & 0 & 0 & 0 & 0 \\
\hline Piciformes & $\mathbf{0} / 7$ & $\mathbf{0}$ & $\mathbf{0}$ & $\mathbf{0}$ & $\mathbf{0}$ & $\mathbf{0}$ & $\mathbf{0}$ \\
\hline Picidade & $0 / 7$ & 0 & 0 & 0 & 0 & 0 & 0 \\
\hline Passeriformes & $22 / 216$ & 10.19 & $1 \mathrm{LC}^{*}$ & 30 & 0.14 & 1.41 & $0-7$ \\
\hline Thamnophilidae & $1 / 2$ & 50 & 0 & 1 & 0.5 & 1 & $0-1$ \\
\hline Dendrocolaptidae & $0 / 1$ & 0 & 0 & 0 & 0 & 0 & 0 \\
\hline Furnariidae & $0 / 3$ & 0 & 0 & 0 & 0 & 0 & 0 \\
\hline Tyrannidae & $13 / 119$ & 10.92 & 0 & 16 & 0.13 & 1.23 & $0-2$ \\
\hline Vireonidae & $0 / 20$ & 0 & 0 & 0 & 0 & 0 & 0 \\
\hline Turdidae & $5 / 27$ & 20.83 & $1 \mathrm{LC}^{*}$ & 4 & 0.19 & 1 & $0-1$ \\
\hline Mimidae & $0 / 5$ & 0 & 0 & 0 & 0 & 0 & 0 \\
\hline Thraupidae & $2 / 32$ & 6.25 & 0 & 8 & 0.25 & 4 & $0-7$ \\
\hline Emberezidae & $0 / 4$ & 0 & 0 & 0 & 0 & 0 & 0 \\
\hline Icteridae & $1 / 3$ & 33.33 & 0 & 1 & 0.33 & 1 & $0-1$ \\
\hline
\end{tabular}

1 LC* $^{*}$ - larval cluster with 51 ticks. 
Table 2. Tick infestation prevalence, abundance, mean intensity and variation of tick-infested bird species, period 2008-2009, in Uberlândia, MG, Brazil.

\begin{tabular}{|c|c|c|c|c|c|c|c|}
\hline Bird species & Infested/examined & Prevalence (\%) & Larvae & Nymphs & Abundance & Mean intensity & Variation \\
\hline Formicivora rufa & $1 / 1$ & 100 & 0 & 1 & 1 & 1 & $0-1$ \\
\hline Elaenia cristata & $4 / 19$ & 21.10 & 0 & 5 & 0.26 & 1.25 & $0-2$ \\
\hline Elaenia chiriquensis & $3 / 51$ & 5.90 & 0 & 4 & 0.08 & 1.33 & $0-2$ \\
\hline Elaenia obscura & $2 / 9$ & 22.20 & 0 & 2 & 0.22 & 1 & $0-1$ \\
\hline Elaenia sp. & $1 / 4$ & 25 & 0 & 1 & 0.25 & 1 & $0-1$ \\
\hline Myiarchus ferox & $1 / 4$ & 25 & 0 & 2 & 0.5 & 2 & $0-2$ \\
\hline Casiornis rufus & $2 / 4$ & 50 & 0 & 2 & 0.5 & 1 & $0-1$ \\
\hline Turdus leucomelas & $3 / 13$ & 23.10 & $1 \mathrm{LC}^{*}$ & 2 & 0.23 & 1 & $0-1$ \\
\hline Turdus amaurochalinus & $2 / 14$ & 14.30 & 0 & 2 & 0.14 & 1 & $0-1$ \\
\hline Saltator similis & $1 / 7$ & 14.30 & 0 & 7 & 1 & 7 & $0-7$ \\
\hline Tangara cayana & $1 / 8$ & 12.50 & 0 & 1 & 0.13 & 1 & $0-1$ \\
\hline Gnorimopsar chopi & $1 / 1$ & 100 & 0 & 1 & 1 & 1 & $0-1$ \\
\hline
\end{tabular}

$1 \mathrm{LC}^{*}$ - larval cluster.

Table 3. Tick species on birds in the reserve of the Clube de Caça e Pesca Itororó, period 2008-2009, in Uberlândia, MG, Brazil.

\begin{tabular}{|c|c|c|c|}
\hline Bird species & Identification & Ticks (n) & Tick species \\
\hline \multicolumn{4}{|l|}{ Thamnophilidade } \\
\hline Formicivora rufa & D 97097 & Nymph (1) & A. nodosum \\
\hline \multicolumn{4}{|l|}{ Tyrannidae } \\
\hline Elaenia cristata & D 49405 & Nymph (1) & A. nodosum \\
\hline Elaenia cristata & D 97021 & Nymph (2) & 1 A. nodosum/ 1 Amblyomma sp. \\
\hline Elaenia cristata & D 97022 & Nymph (1) & A. nodosum \\
\hline Elaenia cristata & D 97079 & Nymph (1) & A. nodosum \\
\hline Elaenia chiriquensis & D 97028 & Nymph (2) & 1 A. nodosum $/ 1$ Amblyomma sp. \\
\hline Elaenia chiriquensis & D 97037 & Nymph (1) & Amblyomma sp. \\
\hline Elaenia chiriquensis & D 97069 & Nymph (1) & Amblyomma sp. \\
\hline Elaenia obscura & E 80854 & Nymph (1) & Amblyomma sp. \\
\hline Elaenia obscura & E 80858 & Nymph (1) & A. nodosum \\
\hline Elaenia sp. & ------- & Nymph (1) & A. nodosum \\
\hline Myiarchus ferox & F 11010 & Nymph (2) & Amblyomma spp. \\
\hline Casiornis rufus & D 97083 & Nymph (1) & A. nodosum \\
\hline Casiornis rufus & E 80894 & Nymph (1) & A. nodosum \\
\hline \multicolumn{4}{|l|}{ Turdidae } \\
\hline Turdus leucomelas & G 77902 & Nymph (1) & A. nodosum \\
\hline Turdus leucomelas & H 68201 & Nymph (1) & Amblyomma sp. \\
\hline Turdus leucomelas & H 68209 & Larvae (5) & A. nodosum \\
\hline T. amaurochalinus & F 11002 & Nymph (1) & Amblyomma sp. \\
\hline T. amaurochalinus & G 77923 & Nymph (1) & Amblyomma sp. \\
\hline \multicolumn{4}{|l|}{ Thraupidae } \\
\hline Saltator similis & G 77912 & Nymph (7) & 1 A. nodosum/ 6 Amblyomma spp. \\
\hline Tangara cayana & D 97038 & Nymph (1) & Amblyomma sp. \\
\hline \multicolumn{4}{|l|}{ Icteridae } \\
\hline Gnorimopsar chopi & H 68205 & Nymph (1) & Amblyomma sp. \\
\hline
\end{tabular}

Ticks ( $\mathrm{n}=31$ ) were found on 22 birds, which were solely Passeriformes, from the following families: Tyrannidae (13), Turdidae (5), Thraupidae (1), Thamnophilidae (1), Icteridae (1) and Cardinalidae (1). Within this order, the prevalence of tick infestation was $10.2 \%$, and the abundance and mean intensity of infestation were 0.14 and 1.41 , respectively (Table 3 ). Considering solely the bird species with more than one individual caught, the prevalence of infestation ranged from 5.9 to $50 \%$ (Table 2). The ticks were identified as Amblyomma nodosum (Neumann, 1899) ( $\mathrm{n}=13$ ) or were retained as Amblyomma sp. larvae or in the case of damaged nymphs unsuitable for identification $(n=18)$ (Table 3$)$.

\section{Ticks on vegetation}

Fifty-eight ticks and also three larval clusters were collected over the two years of sampling (Table 4). The main tick species 
found was Amblyomma cajennense (Fabricius, 1787) (19 adults, 14 nymphs and one larval cluster). Furthermore, one adult and one nymph of Amblyomma dubitatum (Neumann, 1899) and two larval clusters of Rhipicephalus (B.) microplus (Canestrini, 1887) were found. Most of the ticks (74.8\%) were found in the cerrado, whereas both $A$. dubitatum ticks were caught in the vereda.

\section{Ticks from domestic animals}

Overall, on each occasion, 2 to 9 horses, 2 to 9 cattle and 7 to 21 dogs were examined. thus resulting in 26, 28 and 67 evaluations of horses, cattle and dogs, respectively. The prevalence of tick infestation on horses, cattle and dogs was $23.1 \%, 75 \%$ and $25.4 \%$, respectively. Four species of ticks were found on the animals (Table 5). Rhipicephalus (B.) microplus $(\mathrm{n}=166)$ was the only species found on cattle, although this tick species was also found in lesser numbers on dogs and horses. Dermacentor nitens (Neumann, 1897) ( $\mathrm{n}=37$ ) was found only on horses, whereas Rhipicephalus sanguineus (Latreille, 1806) ( $\mathrm{n}=11$ ) was solely on dogs. Amblyomma cajennense $(\mathrm{n}=12)$ was recovered from both dogs and horses.

\section{Hemolymph test}

The hemolymph test was performed on twelve adult ticks and none displayed Rickettsia-like structures.

\section{Discussion}

The sampling at the Reserva Vegetal do Clube de Caça e Pesca Itororo showed that the tick species on birds and in the environment were dissimilar. Whereas only $A$. nodosum was found on birds, $A$. cajennense, $A$. dubitatum and $R$. (B.) microplus was found on the vegetation. Similar results were obtained by Ogrzewalska et al. (2009a), who did not collect any specimens of $A$. nodosum questing tick (in contrast to hundreds of questing $A$. cajennense specimens) in one Atlantic forest area where nearly $10 \%$ of the passerine birds were infested by $A$. nodosum ticks. Such dissimilarity may be explained both by the sampling locations (microenvironment) and by the techniques, which might have been inadequate for ticks questing for birds. Whereas cloth dragging and $\mathrm{CO}_{2}$ traps are more suitable for ambush and hunter ticks, it is possible that bird ticks in the Cerrado are nidicolous and restricted to particular spots. Thus, the precise questing locations of bird ticks should be determined in future observations.

Immature specimens of Amblyomma nodosum, mostly nymphs, have been described previously on several passerine bird species (LABRUNA et al., 2007; OGRZEWALSKA et al., 2009a; TOLESANO-PASCOLI et al., 2010; LUZ et al., 2012), and these hosts seem to be important for its life cycle. Adult $A$. nodosum ticks feed almost exclusively on anteaters (Tamandua tetradactyla and Myrmecophaga tridactyla) (ARAGÃO, 1936; JONES et al., 1972; BECHARA et al., 2002) and, as stated previously (LABRUNA et al., 2007), this tick's distribution seems to be associated with that of its adult hosts. Since anteaters are widely distributed in the Cerrado
(REIS et al., 2006), A. nodosum is expected to be present throughout this biome. However, in bird tick surveys in the Araucaria forest (ARZUA et al., 2003), Amazon rainforest (OGRZEWALSKA et al., 2010) and Atlantic rainforest (OGRZEWALSKA et al., 2008) this tick species was lacking. This might be explained either by a lack of hosts for adults or by an inadequate environment for the off-host life phase of the ticks, a matter that should be investigated.

Our results and those described previously suggest that the life cycle of $A$. nodosum involves anteaters for the adult stage of the ticks to feed on, and various passerine bird species for larvae and nymphs to feed on. Labruna et al. (2007) suggested that groundfeeding passerine birds seem to be the most important species for $A$. nodosum, but in our work several arboreal passerine birds were common hosts as well. In fact, not only ground-feeding birds such

Table 4. Ticks from vegetation in the reserve of the Clube de Caça e Pesca Itororó, period 2007-2009, in Uberlândia, MG, Brazil.

\begin{tabular}{ccc}
\hline \multirow{2}{*}{ Tick species } & \multicolumn{2}{c}{ Phytophysiognomy } \\
\cline { 2 - 3 } & Palm swamp & Cerrado \\
\hline Amblyomma cajennense & & 1 \\
Larva cluster & 8 & 6 \\
Nymphs & $4(3 \mathrm{M} 1 \mathrm{~F})$ & $15(5 \mathrm{M} 10 \mathrm{~F})$ \\
Adults & & \\
Amblyomma dubitatum & 1 & \\
Nymphs & $1(\mathrm{~F})$ & \\
Adults & & \\
Amblyomma spp. & 1 & \\
Nymphs & & \\
Rhipicephalus $($ B. $)$ microplus & 1 & \\
Larva cluster & & \\
\hline
\end{tabular}

Table 5. Tick species and numbers found on domestic animals on farm properties surrounding the cerrado reserve, period 2008-2009, in Uberlândia, MG,Brazil.

\begin{tabular}{|c|c|c|c|}
\hline \multirow{2}{*}{ Tick species } & \multicolumn{3}{|c|}{ Host } \\
\hline & Cattle & Dog & Horse \\
\hline \multicolumn{4}{|c|}{ Amblyomma cajennense } \\
\hline Nymphs & & 7 & \\
\hline Adults & & $\begin{array}{c}3 \\
(1 \mathrm{M} 2 \mathrm{~F})\end{array}$ & $2(1 \mathrm{M} 1 \mathrm{~F})$ \\
\hline \multicolumn{4}{|c|}{ Amblyomma spp. } \\
\hline Nymphs & & 3 & \\
\hline \multicolumn{4}{|c|}{ Dermacentor nitens } \\
\hline Larvae & & & 2 \\
\hline Nymphs & & & 11 \\
\hline Adults & & & $\begin{array}{c}24 \\
(13 \mathrm{M} 11 \mathrm{~F})\end{array}$ \\
\hline \multicolumn{4}{|c|}{ Rhipicephalus (B.) } \\
\hline \multicolumn{4}{|c|}{ microplus } \\
\hline Nymphs & 26 & 2 & 3 \\
\hline Adults & $\begin{array}{c}127 \\
(38 \mathrm{M} 89 \mathrm{~F})\end{array}$ & & $8(5 \mathrm{M} 3 \mathrm{~F})$ \\
\hline \multicolumn{4}{|c|}{ Rhipicephalus sanguineus } \\
\hline Adults & & $\begin{array}{c}11 \\
(9 \mathrm{M} 2 \mathrm{~F})\end{array}$ & \\
\hline
\end{tabular}


as Turdus leucomelas and T. amaurochalinus, but also arboreal species such as Elaenia cristata and Casiornus rufus (SICK, 2004) were infested with $A$. nodosum. Since the observations of Labruna et al. (2007) were predominantly from the Atlantic forest and were restricted to two $A$. nodosum nymphs out of 568 tick specimens, environmental factors and/or low $A$. nodosum sampling might explain this discrepancy. Moreover, since the hosts for adults are terrestrial (Myrmecophaga tridactyla) but also have mixed terrestrial and arboreal habits (Tamandua tetradactyla) (REIS et al., 2006), host questing of $A$. nodosum may be successful in either location for all stages. Nonetheless, $A$. nodosum questing habits, particularly with regard to location, should be addressed by further research.

Finally, one important issue regarding $A$. nodosum is that it may be involved in the epidemiology of rickettsiosis. A spotted-fever group Rickettsia closely related to Rickettsia parkeri was isolated from $A$. nodosum ticks of Passeriformes birds caught in the Atlantic forest (OGRZEWALSKA et al., 2009b).

Another interesting feature of the present work was the lack of A. longirostre, the tick species that was most prevalent on birds in other reports (LABRUNA et al., 2007; OGRZEWALSKA et al., 2008, 2010; TOLESANO-PASCOLI et al., 2010; LUZ et al., 2012). The adult stage of this tick species feeds on porcupines (Coendou spp.) and the immature stages on passerine birds (ARAGÃO, 1936; JONES et al., 1972). Since porcupines are arboreal animals (REIS et al., 2006), forested phytophysiognomies provide a better habitat for both host and tick. Coincidently, in most surveys, $A$. longirostre prevailed over other tick species in forested habitats such as the Atlantic forest (LABRUNA et al., 2007; OGRZEWALSKA et al., 2008), Amazon forest (OGRZEWALSKA et al., 2010) and forested fragments within the Cerrado biome (TOLESANO-PASCOLI et al., 2010; LUZ et al., 2012). Thus, it is possible to speculate that the area sampled in our work ("cerrado sensu stricto"), which has a fair amount of herbaceous vegetation, is less appropriate for $A$. longirostre and its rodent host (porcupine).

The other tick species found on animals or in the environment did not present unexpected features. Rhipicephalus sanguineus is a common tick that infests dogs, $R$. (B.) microplus is the main cattle tick, and $A$. cajennense and $D$. nitens are ticks that infest horses in the Neotropical region (BARROS-BATTESTI et al., 2006). Even though unusual, infestation of dogs with $A$. cajennense and $R$. (B.) microplus and horses with $R$. (B.) microplus can occur if these hosts go through areas infested with these tick species.

Capybaras are the principal host for all parasitic stages of A. dubitatum (NAVA et al., 2010). Albeit in low numbers, this tick species was found in the vereda phytophysiognomy (valley-side marshes), a wetland habitat that is suitable for capybaras (REIS et al., 2006). This finding indicates that capybaras were present at this site. The finding of $R$. (B.) microplus larvae showed that cattle had access to the reserve, an observation also reinforced by the finding of cattle feces during the survey. A. cajennense and Amblyomma spp. nymphs were the main tick species found on the vegetation. Amblyomma is the main tick genus in the Neotropical region (BARROS-BATTESTI et al., 2006) and A. cajennense seems to be the most prevalent species in the cerrado biome (VERONEZ et al., 2010). However, on the whole, the environmental tick infestation of the reserve was very low, thus suggesting that the host density was low.

In conclusion, $A$. nodosum was the main tick species infesting passerine birds in the area. Dissimilar tick species were found on the ground, thus indicating varying host questing activities among the tick species within the cerrado. Nymphs of $A$. nodosum were found on both ground feeding and arboreal birds, and the questing sites of this species are still open to speculation.

\section{Acknowledgements}

This research was supported by the Research Support Foundation of the State of Minas Gerais (Fundação de Amparo à Pesquisa do Estado de Minas Gerais, FAPEMIG), the Federal University of Uberlândia and the National Council for Scientific and Technological Development (Conselho Nacional de Desenvolvimento Científico e Tecnológico, CNPq) for a master's fellowship to J.O.P. and an academic career research fellowship to M.B.L. and M.P.J.S.. The authors are indebted to Clube Caça e Pesca Itororó and CEMAVE for permissions.

\section{References}

Aragão HB. Ixodidas brasileiros e de alguns paizes limitrophes. Mem Inst Oswaldo Cruz 1936; 31(4): 759-843. http://dx.doi.org/10.1590/ S0074-02761936000400004

Arzua M, Barros-Battesti DM. Parasitism of Ixodes (Multidentatus) auritulus Neumann (Acari: Ixodidae) on Birds from the City of Curitiba, State of Paraná, Southern Brazil. Mem Inst Oswaldo Cruz 1999; 94(5): 597-603. PMid:10464400. http://dx.doi. org/10.1590/S0074-02761999000500006

Arzua M, Silva MAN, Famadas KM, Beati L, Barros-Battesti DM. Amblyomma aureolatum and Ixodes auritulus (Acari: Ixodidae) on birds in southern Brazil, with notes on their ecology. Exp Appl Acarol 2003; 31(3-4): 283-296. PMid:14974693. http://dx.doi. org/10.1023/B:APPA.0000010381.24903.1c

Barros-Battesti DM, Arzua M, Bechara HG. Introdução. In: BarrosBattesti DM, Arzua M, Bechara HG. Carrapatos de importância medicoveterinária da região neotropical: um guia ilustrado para identificação de espécies. São Paulo: Vox, ICTTD-3, Butantan; 2006. p. 1-2.

Bechara GH, Szabó MPJ, Almeida Filho WV, Bechara JN, Pereira RJG, Garcia JE, et al. Ticks Associated with Armadillo (Euphractus sexcinctus) and Anteater (Myrmecophaga tridactyla) of Emas National Park, state of Goias, Brazil. Ann N Y Acad Sci 2002; 969: 290-293. PMid:12381607. http://dx.doi.org/10.1111/j.1749-6632.2002.tb04394.x

Burgdorfer W. Hemolymph test. A technique for detection of Rickettsiae in ticks. The Am J Trop Med Hyg 1970; 19(6): 1010-1014. PMid:4992724.

Bush AO, Lafferty KD, Lotz JM, Shostak AW. Parasitology meets ecology on its own terms: Margolis et al. revisited. J Parasitol 1997; 83(4): 575583. PMid:9267395. http://dx.doi.org/10.2307/3284227

Comitê Brasileiro de Registros Ornitológicos - CBRO. Epi Info [online]. 2011 [cited 2012 Jan 20]. Available from: http://www.cbro. org.br/CBRO/index.htm.

Dantas-Torres F, Onofrio VC, Barros-Battesti DM. The ticks (Acari: Ixodida: Argasidae, Ixodidae) of Brazil. Syst ApplAcarol2009; 14(1): 30-46. 
Jones EK, Clifford CM, Keirans JE, Kohls GM. The ticks of Venezuela (Acarina: Ixodoidea) with a key to the species of Amblyomma in the western hemisphere. Brigham Young Univ Sci Bull Biol Ser 1972; 17(4): 1-40.

Jongejan F, Uilenberg G. The global importance of ticks. Parasitology 2004; 129(S1): 3-14.

Kanegae MF. Comparação dos padrōes de ectoparasitismo em aves de Cerrado e de Mata de Galeria do Distrito Federal [Dissertação]. Brasília: Universidade de Brasília; 2003.

Labruna MB, Sanfilippo LF, Demetrio C, Menezes AC, Pinter A, Guglielmone AA, et al. Ticks collected on birds in the state of São Paulo, Brazil. Exp Appl Acarol 2007; 43(2): 147-160. PMid:17882514. http:// dx.doi.org/10.1007/s10493-007-9106-x

Luz HR, Faccini JLH, Landulfo GA, Berto BP, Ferreira I. Bird ticks in an area of the Cerrado of Minas Gerais State, southeast Brazil. Exp Appl Acarol 2012; 58(1): 89-99. PMid:22729500. http://dx.doi.org/10.1007/ s10493-012-9572-7

Marini MÂ, Couto D. Correlações ecológicas entre ectoparasitas e aves de florestas de Minas Gerais. In: Leite LL, Saito CH. Contribuição ao Conhecimento Ecológico do Cerrado. Brasília: Departamento de Ecologia, Universidade de Brasília; 1997. p. 210-218.

Martins TF, Onofrio, VC, Barros-Battesti DM, Labruna MB. Nymphs of the genus Amblyomma (Acari: Ixodidae) of Brazil: descriptions, redescriptions, and identification key. Ticks Tick Borne Dis 2010; 1(2): 75 99. PMid:21771514. http://dx.doi.org/10.1016/j.ttbdis.2010.03.002

Myers N, Mittermeier RA, Mittermeier CG, Fonseca GAB, Kent J. Biodiversity hotspots for conservation priorities. Nature 2000; 403: 853858. PMid:10706275. http://dx.doi.org/10.1038/35002501

Nava S, Venzal JM, Labruna MB, Mastropaolo M, González EM, Mangold AJ, et al. Hosts, distribution and genetic divergence (16S rDNA) of Amblyomma dubitatum (Acari: Ixodidae). Exp Appl Acarol 2010; 51(4): 335-351. PMid:20084537. http://dx.doi. org/10.1007/s10493-009-9331-6

Ogrzewalska M, Pacheco RC, Uezu A, Ferreira F, Labruna MB. Ticks (Acari: Ixodidae) Infesting Wild Birds in an Atlantic Forest Area in the State of São Paulo, Brazil, with Isolation of Rickettsia from the Tick Amblyomma longirostre. J Med Entomol 2008; 45(4): 770-774. http:// dx.doi.org/10.1603/0022-2585(2008)45[770:TAIIWB]2.0.CO;2

Ogrzewalska M, Pacheco RC, Uezu A, Richtzenhain LJ, Ferreira F, Labruna MB. Ticks (Acari: Ixodidae) infesting birds in Atlantic Rain Forest region of Brazil. J Med Entomol 2009a; 46(5): 1225-1229. PMid:19769058. http://dx.doi.org/10.1603/033.046.0534

Ogrzewalska M, Pacheco RC, Uezu A, Richtzenhain LJ, Ferreira F, Labruna MB. Rickettsial infection in Amblyomma nodosum ticks (Acari: Ixodidae) from Brazil. Ann Trop Med Parasitol 2009b; 103(5): 413-425. PMid:19583912. http://dx.doi.org/10.1179/136485909X451744

Ogrzewalska M, Uezu A, Labruna MB. Ticks (Acari: Ixodidae) infesting wild birds in the eastern Amazon, northern Brazil, with notes on rickettsial infection in ticks. Parasitol Res 2010; 106(4): 809-816. PMid:20140452. http://dx.doi.org/10.1007/s00436-010-1733-1

Ogrzewalska M, Uezu A, Labruna MB. Ticks (Acari: Ixodidae) infesting wild birds in the Atlantic Forest in northeastern Brazil, with notes on rickettsial infection in ticks. Parasitol Res 2011; 108(3): 665-670 PMid:20953629. http://dx.doi.org/10.1007/s00436-010-2111-8

Onofrio VC, Labruna MB, Pinter A, Giacomin FG, Barros-Battesti DM. Comentários e chaves para as espécies de Amblyomma. In: Barros-Battesti DM, Arzua M, Bechara HG. Carrapatos de importância médico-veterinária da regiāo neotropical: um guia ilustrado para identificação de espécies. São Paulo: Vox, ICTTD-3, Butantan; 2006. p. 53-71.

Ostfeld RS, Keesing F. Biodiversity and disease risk: the case of Lyme disease. Conserv Biol 2000; 14(3): 722-728. http://dx.doi.org/10.1046/ j.1523-1739.2000.99014.x

Paddock CD. The science and fiction of emerging Rickettsioses. Ann N Y Acad Sci 2009; 1166: 133-143. PMid:19538273. http://dx.doi org/10.1111/j.1749-6632.2009.04529.x

Queirogas VL, Del Claro K, Nascimento ART, Szabó MPJ. Capybaras and ticks in the urban areas of Uberlândia, Minas Gerais, Brazil ecological aspects for the epidemiology of tick-borne diseases. Exp Appl Acarol 2012; 57(1): 75-82. PMid:22349945. http://dx.doi.org/10.1007/ s10493-012-9533-1

Reis NR, Peracchi AL, Pedro WA, Lima IP. Mamíferos do Brasil. Londrina: Universidade Estadual de Londrina; 2006.

Ridgely RS, Tudor G. The Birds of South America. I. The Oscine Passerines. Oxford: University Press; 1989.

Ridgely RS, Tudor G. The Birds of South America. II. The Suboscine Passerines. Oxford: University Press; 1994.

Rojas R, Marini MA, Coutinho MTZ. Wild birds as hosts of Amblyomma cajennense (Fabricius, 1787) (Acari: Ixodidae). Mem Inst Oswaldo Cruz 1999; 94(3): 315-322. PMid:10419381. http://dx.doi. org/10.1590/S0074-02761999000300007

Sick H. Ornitologia Brasileira. 3. ed. Rio de Janeiro: Editora Nova Fronteira; 2004.

Silva JMC. Birds of the Cerrado region, South America. Steenstrupia 1995; 21: 69-92.

Silva JF, Fariñas MR, Felfili JM, Klink CA. Spatial heterogeneity, land use and conservation in the Cerrado region of Brazil. J Biogeogr 2006; 33(3): 536-548. http://dx.doi.org/10.1111/j.13652699.2005.01422.x

Szabó MPJ, Olegário MMM, Santos ALQ. Tick fauna from two locations in the Brazilian savannah. Exp Appl Acarol 2007; 43(1): 73-84. PMid:17828441. http://dx.doi.org/10.1007/s10493-007-9096-8

Tolesano-Pascoli GV, Torga K, Franchin AG, Ogrzewalska M, Gerardi M, Olegário MMM, et al. Ticks on birds in a forest fragment of Brazilian cerrado (savanna) in the municipality of Uberlândia, State of Minas Gerais, Brazil. Rev Bras Parasitol Vet 2010; 19(4): 244-248. PMid:21184702. http://dx.doi.org/10.1590/S1984-29612010000400010

Veronez VA, Freitas BZ, Olegário MMM, Carvalho WM, Pascoli GVT, Thorga K, et al. Ticks (Acari: Ixodidae) within various phytophysiognomies of a cerrado reserve in Uberlândia, Minas Gerais, Brazil. Exp Appl Acarol 2010; 50(2): 169-179. PMid:19693680. http:// dx.doi.org/10.1007/s10493-009-9294-7 